\title{
Bayesian analysis on the growth traits in nelore mocho cattle raised in cerrado biome
}

\author{
Carina Ubirajara Faria*, Paulo Henrique Rezende Guimarães ${ }^{1}$, \\ Mariana Mundim Alves Gomes, Joice de Medeiros Miguel, \\ Lucas de Oliveira Lemos, Letícia Silva Pereira, Raysildo Barbosa Lôbo
}

\begin{abstract}
This paper aims to estimate the (co) variances components on the genetic parameters for growth traits in Nelore Mocho cattle, raised in Cerrado biome, using Bayesian statistics. The data has been obtained from 48,063 cattle, provenient of Nelore Mocho herd, born from 1987 to 2009, participant of Breeder and Research Nacional Association's (ANCP) Nelore Brazil Program. It has been evaluated the standard weight in 120 (P120), 210 (P210), 365 (P365), 450 (P450) years old, the weight gain from the birth to the weaning (GPND), and the weight gain from weaning to yearling (GPDS). The estimates on (co) variances components and genetic parameters have employed univariate analyses considering the Bayesian statistics animal model by the MTGSAM (Multiple Trait using Gibbs Sampler under Animal Model). The estimated values for direct heritability ranged from medium to high magnitude in standard weights (with range of 0.23 to 0.33 ) and the weight gain (0.18 for GPND and 0.24 for GPDS), for the creates and recreates phase, respectively. These results indicate that there is genetic variability in Nelore Mocho herd for growth traits, showing effective genetic growth when using the direct selection of these features in genetic improvement programs.
\end{abstract}

Keywords: Beef cattle; Heritability; Selection.

\section{Introduction}

The Brazilian beef cattle industry, an outstanding highlight in agribusiness, with national effective of approximately 212 million cattle, ranks third in importance. Most of Brazilian cattle is produced in the

\footnotetext{
${ }^{1}$ Faculdade de Medicina Veterinária da Universidade Federal de Uberlândia

${ }^{2}$ Associação Nacional de Criadores e Pesquisadores

* Corresponding author: Faculdade de Medicina Veterinária, Sala 1C202, Campus Glória, Uberlândia, MG, email: carina@ufu.br 
Cerrado, where herding consists of zebu cattle well adapted to tropical conditions, the Nelore and Nelore Mocho that account for almost $90 \%$ of zebu (Bos indicus) present in Brazil (ABIEC, 2012).

Despite this favorable scenario, the economic agents involved in cattle meat production and marketing acknowledge the need to improve productivity levels; therefore, increasing the country's competitiveness in the international market. However, there are few studies addressing estimates of genetic parameters for growth traits in Nelore Mocho cattle (SOUZA et al., 2004; LIMA et al., 2005; MALHADO et al., 2005; SANTOS et al. 2005), as well as those focusing on cattle in the Cerrado.

Traditionally, the Restricted Maximum Likelihood (REML) method is the most widely adopted in genetic evaluation programs. Opposing this trend, several studies employed new methods for obtaining estimates of (co) variance components and genetic parameters (FARIA et al, 2007). Among these, there is the Bayesian analysis, made possible by Gibbs Sampling from the methods of Markov Chain Monte Carlo (MCMC), which considers the population parameters as random variables and enables integrating prior probabilities (a priori) in the data, resulting in posterior probabilities (a posteriori) and consequently better accuracy (VAN TASSEL \& VAN VLECK, 1996).

From the knowledge on estimates of variance components and genetic parameters for growth traits, new selection indices will be used to identify superior genotypes in different production systems, accelerating genetic progress of the cattle herds of Nelore Mocho breed. Thus, this study aims to estimate the components of (co) variance and genetic parameters for growth traits in Nelore Mocho cattle bred in the Cerrado biome by using Bayesian statistics. 


\section{Material and methods}

The data set consisted of 48,063 measurements of cattle born between 1987 and 2009, from herds of Nelore Mocho breed, participant in the Nelore Brazil Program of the National Association of Breeders and Researchers (ANCP). Those animals have been raised on pasture in the Cerrado biome, from Brazilian states with the largest continuous areas of this biome, such as the states of Goiás, Minas Gerais, Mato Grosso, Mato Grosso do Sul and Tocantins.

We have evaluated 48,046 standardized weights at 120 (P120), 39,615 to 210 (P210), 26,752 to 365 (P365) and 22,869 to 450 (P450) days old, in addition to 27,428 data on weight gain from birth to weaning (GPND) and 22,477 weight gain from weaning to yearling (GPDS). For descriptive statistical analysis and formation of contemporary groups the Statistical Analysis System (SAS, 2004) has been used.

In the formation of contemporary groups for the growth traits, the study has considered grouping the animals born on the same farm, the same year same birth season, same sex and same management batch. The effect of birth season resulted into four classes division: animals born between February and April, from May to July, August to October, and from November to January, according to the distribution of births that commonly occur in this biome.

In the database formatting was considered the elimination of groups with less than four animals. Beyond this restriction, outliers were also removed, which corresponded to animals with measurements of 3.5 standard deviations from the median of contemporary group. The formation of contemporary groups resulted in 2,136 groups for characteristic P120; 2,239 to P210; 1,750 to P365; 1,593 to P450; 1,676 for GPND and 1,555 for GPDS. The relationship matrix included 280,779 animals, at least seven generations. 
Single-trait analyses were performed using the MTGSAM application (Multiple Trait using Gibbs Sampler under Animal Model) developed by Van Tassel \& Van Vleck (1996). The animal model is represented in matrix notation:

$$
y=X \beta+Z_{1} a+Z_{2} m+Z_{3} c+e
$$

where $y$ is the vector of observations, $\beta$ is the vector of fixed effects, $a$ is the vector of random effects which represent the additive genetic values from each animal, $m$ is the vector of random effects that represent the maternal additive breeding values, $c$ is the vector of uncorrelated random effects (maternal permanent environment), $e$ the vector of random residual effects, and $X, Z_{1}, Z_{2}$ e $Z_{3}$ are the incidence matrices relating observations to fixed effects and maternal and direct additive genetic random effects and uncorrelated, respectively.

For all growth traits were assumed as fixed effects the contemporary groups (CG) and the age class at calving (CIVP), while the latter was divided into: less than or equal to three years, three to four years; four to five years; five to six years, six to ten and greater than ten. Note that while carrying on the Bayesian statistics all the effects are considered random effects.

In implementing the Gibbs sampling, we considered the size of the initial chain of 300,000 cycles, so that the first 50,000 cycles were discarded, and sampled every 1,000 cycles; thus, totaling 250 samples. The convergence criterion adopted was $10^{-9}$.

To verify the accuracy of the estimates was used the Monte Carlo method to assess error, obtained by the square root of the value found in the division of the variance of each feature by the number of samples (VAN TASSEL \& VAN VLECK, 1996). 


\section{Results and discussion}

The mean indexes of Nelore Mocho breed, the mean values, standard deviation, coefficient of variation, minimum and maximum values for growth traits have been measured and are presented on Table 1.

The result obtained for P120 (126 $\pm 20.11 \mathrm{~kg})$ was similar to those found in the literature for Nelore, $126 \pm 20.11 \mathrm{~kg}$ by GARNERO et al. (2001) and $121 \mathrm{~kg}$ by SIQUEIRA et al. (2003). The mean value found for P210 (184 $\pm 29.27 \mathrm{~kg})$ was similar to that found by Conceição et al. (2005) and Payá et al. (2007), who worked on standardized weights at 205 days of age (P205) of Nelore Mocho cattle. In the southwestern state of Mato Grosso do Sul, Conceição et al. (2005) evaluated 21,919 animals from 1975 to 2001 and found mean of $181.30 \mathrm{~kg}$. Payá et al. (2007), working on the sub region of Campinas, found mean adjusted weight of $187.34 \mathrm{~kg}$. According to Ferreira et al. (2014), the average obtained weights at 205 days of age (P205) of Nelore cattle reared in pasture in the northern region of Brazil was $176.08 \mathrm{~kg}$. Sena (2013) found an average of $184 \mathrm{~kg}$ for P210 days in Nelore animals raised in the Amazonia Legal region.

The results observed in this study for the characteristic P365 (238 \pm $38.64 \mathrm{~kg}$ ) has also been similar to those found by Payá et al. (2007) and Ferreira et al. (2014), who highlight a mean value of $269.23 \mathrm{~kg}$ and 228.42 kg, respectively. Ferraz Filho et al. (2002) obtained mean value of $221.38 \mathrm{~kg}$ for P365, working on 5,924 observations from animals born from 1981 to 1992 in the Midwest, Northeast and Southeast Brazil. Experiment by Amaral et al. (2014), carried out on cattle of the Nelore Mocho variety, belonging to herds located in the region Northeast Brazil, has found an average weight of $232.90 \mathrm{~kg}$ at 365 days of age. 
Table 1. Descriptive statistics of the grow traits 120 (P120), 210 (P210), 365 (P365) and 450 (P450) days of age, weight gain from birth to weaning (GPND) and weight gain from weaning to yearling (GPDS) in Nelore Mocho cattle, raised on pasture in Cerrado biome.

\begin{tabular}{ccccc}
\hline Trait & $\begin{array}{c}\text { Mean } \pm \text { Standard } \\
\text { Deviation }\end{array}$ & $\begin{array}{c}\text { Minimum } \\
\text { Value }\end{array}$ & $\begin{array}{c}\text { Maximum } \\
\text { Value }\end{array}$ & $\begin{array}{c}\text { Coefficient of } \\
\text { Variation (\%) }\end{array}$ \\
\hline P120 $(\mathrm{kg})$ & $126 \pm 20.11$ & 54 & 222 & 15.93 \\
P210 $(\mathrm{kg})$ & $184 \pm 29.27$ & 74 & 316 & 15.87 \\
P365 $(\mathrm{kg})$ & $238 \pm 38.64$ & 107 & 517 & 16.26 \\
P450 $(\mathrm{kg})$ & $277 \pm 46.96$ & 135 & 589 & 16.94 \\
GPND $(\mathrm{kg})$ & $149 \pm 28.87$ & 43 & 274 & 19.41 \\
GPDS $(\mathrm{kg})$ & $88 \pm 33.03$ & -43 & 278 & 37.61 \\
\hline
\end{tabular}

For P450, the result $(277 \pm 46.96 \mathrm{~kg})$ was similar than those found by Siqueira et al. (2003) and Sena (2013), respectively, $250 \pm 44.00 \mathrm{~kg}$ and 262 $\pm 45.50 \mathrm{~kg}$. All these studies used Nelore cattle reared in different Brazilian regions. The value obtained in this work for the GPND $(149 \pm 28.87 \mathrm{~kg})$ was similar than that observed by Marcondes et al. (2000), who found a $155 \mathrm{~kg}$ weight gain of Nelore cattle, and the gain of $141.47 \mathrm{~kg}$ found by Laureano et al. (2011) who used records of 128,148 animals from Nelore breed, born between the years 1984 and 2006, coming from an agricultural company dedicated to beef cattle breeding, located in the state of São Paulo. Studying animals of Angus breed, Cardoso et al. (2001) found $124 \mathrm{~kg}$ weight gain from birth to 205 days of age.

The GPDS $(88 \pm 33.03 \mathrm{~kg})$ was similar from that found by Marcondes et al. (2000) and Laureano et al. (2011) who obtained $119 \mathrm{~kg}$ and $100.93 \mathrm{~kg}$, respectively, working on Nelore. Similar values has also been observed by Cardoso et al. (2004) when evaluated post-weaning weight gain at 205 days for Angus animals, whose results indicated $72 \mathrm{~kg}$ with $33 \mathrm{~kg}$ standard deviation.

When confronted the phenotypic values of GPND and GPDS, there is a lower weight gain in the growing phase compared to the period from birth to weaning. These values can be explained due to weaning occurs at the end of the rainy season. Moreover, much of the period evaluated to estimate the weight gain from weaning to yearling occurs mainly in the dry season that, 
due to the smaller forage supply and quality reduction, promotes weight loss in animal rearing. It is found that the coefficient of variation was $37.61 \%$ for the GPDS showing the greatest variation of the phenotypic data, which may indicate a greater influence of the environmental effect.

When evaluating the posterior distributions of estimates of genetic parameters for growth, it has been found that the Monte Carlo errors were low (Table 2) for both the direct heritability and maternal heritability indicating that the size of the Gibbs chain was sufficient to obtain accurate estimates of the later means. The Monte Carlo error is considered small when its value added to the mean estimate of heritability distribution does not change the value of this estimate to the second decimal (FARIA et al., 2008).

Table 2. Monte Carlo error estimates of direct and maternal heritability for traits standardized to 120 (P120), 210 (P210), 365 (P365) and 450 (P450) days old weight, weight gain from birth to weaning (GPND) and weight gain from weaning to yearling (GPDS) in Nelore Mocho cattle, raised on pastures in the Cerrado biome.

\begin{tabular}{ccc}
\hline Trait & \multicolumn{2}{c}{ Monte Carlo Error Estimates } \\
\cline { 2 - 3 } & Direct heritability & Maternal heritability \\
\hline P120 & 0.0012 & 0.0010 \\
P210 & 0.0014 & 0.0008 \\
P365 & 0.0016 & 0.0010 \\
P450 & 0.0018 & 0.0007 \\
GPND & 0.0012 & 0.0011 \\
GPDS & 0.0017 & 0.0010 \\
\hline
\end{tabular}

The Table 3 shows the estimates of (co) variance components and genetic parameters for growth traits in Nelore Mocho cattle. It resulted that the values of mean, mode and median were similar for all parameters estimated indicating that the posterior marginal distributions tend to a symmetrical distribution. According to Silva et al. (2005), the symmetry of the estimates of central tendency is indicative of convergence of Gibbs sampling chain and an accurate analysis. Convergence is reached when the cycles to determine each parameter in the Gibbs sampling are repeated 
many times, tending to a stationary distribution in equilibrium (VAN TASSEL \& VAN VLECK, 1996).

Direct heritability estimates for P120 was 0.23 , which can be considered of medium magnitude. However, it proves the existence of genetic variability in the Nelore Mocho population. Similar estimates have been found by Gunski et al. (2001), Siqueira et al. (2003), Garnero et al. (2010) and Sena et al. (2013), who had mean values of 0.27, 0.29, 0.23 and 0.24 respectively for Nelore cattle reared in Brazil. Considering the estimate of maternal heritability (0.12), mean values were also similar to those of Siqueira et al. (2003) and Gunski et al. (2001), who found mean average values of 0.08 and 0.16 , respectively, for Nelore cattle by using the Bayesian inference and working on animals from Nelore breed. Nepomuceno et al. (2013) has also found similar mean values ranging from 0.12 to 0.19 when evaluating Nelore cattle reared in pasture in the states of Maranhão, Mato Grosso and Pará.

The mean direct heritability estimated for P210 (0.23) indicated medium magnitude, similar to that found by Malhado et al. (2005) and Laureano et al. (2011) and superior to those found by Souza et al. (2004) and Lima et al. (2005) and Silva et al. (2013). These authors have obtained values of $0.24,0.23,0.16,0.17$ and 0.13 for direct heritability, respectively, working on Nelore Mocho and using different statistical models and standardized weights at 205 days of age. In this context, Silva et al. (2012), evaluated 6,340 animals of Brangus from the south, southeast and centerwest of Brazil and also found values of medium magnitude of 0.24. For maternal heritability for P210 was estimated the value with lower magnitude compared to the P120, 0.10 and 0.12 , respectively.

The mean estimate of direct heritability for P365 was 0.28 , and accompanied the median values obtained for the characteristic P120 and P210, unlike maternal heritability that showed lower magnitude, with range of 0.04 a 0.12 . The estimated value for direct heritability P365 was 
lower than that estimated by Faria et al. (2007). These authors, conducting studies using the Bayesian analysis and Nelore animals found results of 0.49. Previous studies by Gonçalves et al. (2011) and Silva et al. (2013) have also estimated, for Nelore cattle, higher heritability than those found in this study for P365. The mean values estimated for direct heritability of P450 had high magnitude, 0.33, the same has been found by Faria et al. (2007) and Sena et al. (2013).

As shown in Table 3, estimates of direct heritabilities were higher for growth traits evaluated in the growing phase compared to the traits assessed in the rearing phase. Consequently, it suggests greater genetic variability for growth traits at yearling which allows obtaining greater genetic progress with the selection. Thus, the inclusion of P450 in developing selection indices for Nelore Mocho cattle reared in the Cerrado biome is recommended.

Table 3. Estimates of mean (co) variance components and genetic parameters for grow traits 120 (P120), 210 (P210), 365 (P365) and 450 (P450) days of age in Nelore Mocho cattle, raised on pastures in the Cerrado biome.

\begin{tabular}{|c|c|c|c|c|}
\hline Trait & Mean & Mode & Median & Region of credibility (95\%) \\
\hline $\mathrm{P} 120$ & & & & \\
\hline$\sigma^{2}$ & 50.68 & 49.63 & 50.33 & 41.22 a 60.07 \\
\hline$\sigma_{a m}$ & -11.34 & -11.69 & -11.50 & -17.58 a -6.06 \\
\hline$\sigma^{2}$ & 26.76 & 27.08 & 26.54 & 20.76 a 34.70 \\
\hline$\sigma^{2}$ & 37.68 & 37.73 & 37.68 & 33.58 a 41.58 \\
\hline$\sigma^{2}$ & 117.00 & 116.19 & 116.90 & 111.61 a 122.30 \\
\hline$h^{2}$ & 0.23 & 0.22 & 0.23 & 0.19 a 0.27 \\
\hline$h_{\ldots}^{2}$ & 0.12 & 0.12 & 0.12 & 0.09 a 0.16 \\
\hline $\begin{array}{l}r_{r m} \\
\mathrm{P} 210\end{array}$ & -0.31 & -0.31 & -0.31 & -0.43 a -0.18 \\
\hline$\sigma^{2}$ & 101.59 & 100.02 & 100.41 & 85.77 a 123.52 \\
\hline$\sigma_{a m}$ & -16.83 & -18.61 & -16.50 & -29.72 a -6.71 \\
\hline$\sigma_{\ldots}^{2}$ & 44.03 & 41.76 & 43.27 & 34.33 a 55.62 \\
\hline$\sigma^{2}$ & 80.09 & 79.68 & 79.84 & 72.60 a 87.44 \\
\hline$\sigma^{2}$ & 216.63 & 218.12 & 217.35 & 205.15 a 226.88 \\
\hline$h^{2}$ & 0.23 & 0.23 & 0.23 & 0.20 a 0.27 \\
\hline$h_{\ldots}^{2}$ & 0.10 & 0.09 & 0.10 & 0.08 a 0.13 \\
\hline $\begin{array}{l}r_{a m} \\
\text { P365 }\end{array}$ & -0.25 & -0.28 & -0.25 & -0.39 a -0.11 \\
\hline$\sigma^{2}$ & 148.75 & 143.32 & 146.91 & 123.00 a 177.80 \\
\hline$\sigma_{a m}$ & -28.05 & -24.44 & -26.76 & -45.89 a -15.26 \\
\hline
\end{tabular}




\begin{tabular}{|c|c|c|c|c|}
\hline$\sigma_{\ldots}^{2}$ & 37.55 & 34.60 & 36.40 & 23.90 a 55.49 \\
\hline$\sigma^{2}$ & 56.45 & 53.58 & 56.62 & 45.92 a 66.19 \\
\hline$\sigma^{2}$ & 316.36 & 318.63 & 316.60 & 295.39 a 333.45 \\
\hline$h^{2}$ & 0.28 & 0.27 & 0.28 & 0.23 a 0.33 \\
\hline$h_{\ldots}^{2}$ & 0.07 & 0.06 & 0.07 & 0.04 a 0.10 \\
\hline $\begin{array}{l}r_{a m} \\
\mathrm{P} 450\end{array}$ & -0.37 & -0.35 & -0.37 & -0.52 a -0.24 \\
\hline$\sigma^{2}$ & 203.05 & 203.62 & 203.19 & 167.22 a 242.71 \\
\hline$\sigma_{a m}$ & -34.76 & -35.48 & -34.35 & -53.36 a -19.92 \\
\hline$\sigma_{\ldots}^{2}$ & 26.26 & 27.71 & 26.93 & 13.45 a 38.77 \\
\hline$\sigma^{2}$ & 50.39 & 47.83 & 49.93 & 39.18 a 62.92 \\
\hline$\sigma^{2}$ & 358.34 & 355.74 & 357.23 & 336.63 a 381.79 \\
\hline$h^{2}$ & 0.33 & 0.33 & 0.33 & 0.28 a 0.39 \\
\hline$h_{\ldots}^{2}$ & 0.04 & 0.04 & 0.04 & 0.02 a 0.06 \\
\hline$r_{a m}$ & -0.48 & -0.50 & -0.48 & -0.63 a -0.24 \\
\hline
\end{tabular}

$\overline{\sigma_{a}^{2}}=$ genetic variance components direct additive genetic; $\sigma_{a m}=$ covariance between direct and maternal additive effects; $\sigma_{m}^{2}=$ direct additive maternal genetic variance; $\sigma_{a p m}^{2}$ $=$ maternal permanent environmental variance; $\sigma_{e}^{2}=$ residual variance; $h_{d}^{2}=$ direct heritability; $h_{m}^{2}=$ maternal heritability and $r_{a m=\text { genetic correlation between direct and }}$ maternal additive effects.

With regard to the characteristics GPND and GPDS, the direct heritability estimates were of medium magnitude, 0.18 and 0.24, respectively (Table 4). The direct heritability estimate for GPND was similar than observed by Cardoso et al. (2001) who used data on weight gain from birth to weaning in Angus breed animals obtaining a result of 0.25. It did not occur with the direct heritability estimated by Cardoso et al. (2004) for post-weaning weight gain of Angus cattle whose value was 0.20. The results obtained by Laureano et al. (2011) compared the estimates of maternal heritability of GPND and GPDS, and direct heritability to GPDS were lower than those obtained in this study, being 0.06, 0.04 and 0.23, respectively. That same author has obtained a result of 0.21 of direct estimate of heritability, higher than that found on this study.

Albuquerque and Meyer (2001) reported that with the animal aging the maternal additive genetic effect decreases, which it has also been observed in this study on the analysis of the maternal heritability that decreased with increasing age of animals. However, estimates of maternal 
heritability for growth traits evaluated in the growing phase were not zero, which proves the influence of maternal effect on the phenotype of growth characteristics evaluated annually and yearling and therefore, there is need to include this effect in models of genetic analysis.

The average estimates for components of covariance between direct and maternal effects were negative for all growth traits evaluated, as well as the genetic correlation between direct and maternal additive effects, indicating antagonism between direct and maternal additive genetic effect.

Importantly, since few studies have been found on the estimation of genetic parameters for production traits in Nelore Mocho cattle and further research is recommended, given the increased breed population and its importance to the Brazilian cattle industry.

Table 4 Estimates of mean (co) variance components and genetic parameters for weight gain from birth to weaning (GPND) and weight gain from weaning to yearling (GPDS) in Nelore Mocho cattle, raised on pastures in the Cerrado biome.

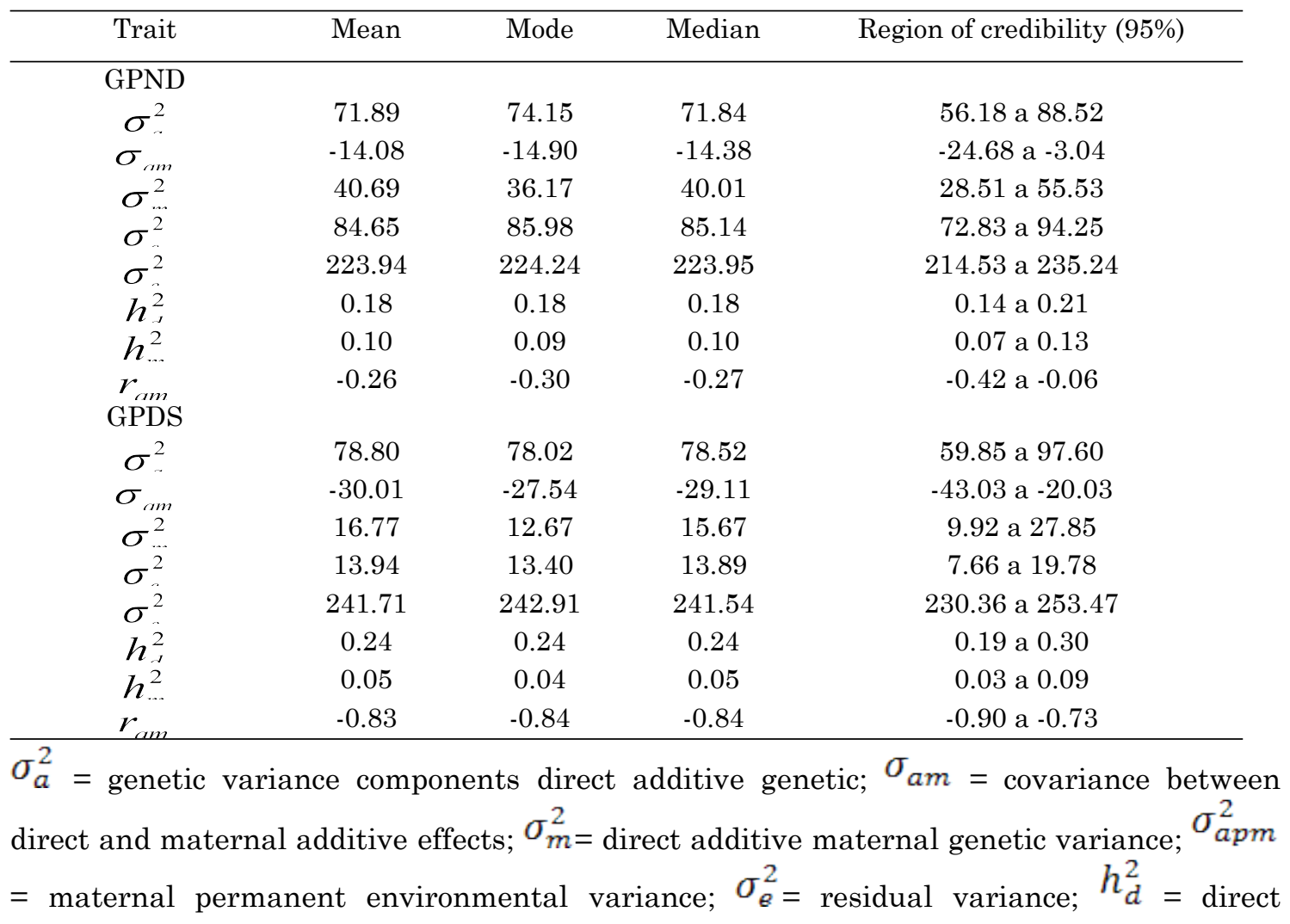


heritability; $h_{m}^{2}=$ maternal heritability and $r_{a m=\text { genetic correlation between direct and }}$ maternal additive effects.

\title{
Conclusion
}

This study sought to estimate the (co) variances components on the genetic parameters for growth traits in Nelore Mocho cattle, raised in Cerrado biome, in Brazil. By using Bayesian statistics, it comes to conclusion that the direct heritability estimates were of medium to high magnitude, indicating the existence of genetic variability for growth traits in Nelore Mocho cattle. Those statistical results lead to recommend the inclusion of yearling weight (P450) in the selection indices for Nelore Mocho cattle, for the improvement of the herd

\section{Acknowledgements}

We are grateful to the ANCP and CNPq for providing the data and technical-scientific support.

\section{$* * *$ \\ Análise bayesiana para características de crescimento em bovinos da raça nelore mocho criados em bioma cerrado}

\begin{abstract}
RESUMO
O objetivo deste estudo foi estimar os componentes de (co) variância e parâmetros genéticos para as características de crescimento de bovinos da raça Nelore Mocho criados em bioma Cerrado, utilizando a inferência bayesiana. As informações foram obtidas de 48.063 animais Nelore Mocho, nascidos entre 1987 a 2009, provenientes de rebanhos participantes do Programa Nelore Brasil da Associação Nacional de Criadores e Pesquisadores (ANCP). Foram avaliadas as características de pesos padronizados aos 120 (P120), 210 (P210), 365 (P365) e 450 (P450) dias de idade, além do ganho de peso do nascimento a desmama (GPND) e o ganho de peso da desmama ao sobreano (GPDS). Os componentes de (co) variância e parâmetros genéticos foram estimados por meio de análises uni-características considerando a estatística bayesiana sob modelo animal
\end{abstract}


e utilizando o programa MTGSAM (Multiple Trait using Gibbs Sampler under Animal Model). Os valores estimados para as herdabilidades foram de média a alta magnitude para todas as características de pesos padronizados (variando de 0,23 a 0,33 ) e de média magnitude para as características de ganho em peso (0,18 para GPND e 0,24 para GPDS). As herdabilidades estimadas indicaram a existência de variabilidade genética para as características de crescimento na raça Nelore Mocho, portanto, a seleção direta para tais características trará progresso genético apreciável.

Palavras-chave: Bovinos de Corte; Herdabilidade; Seleção.

$* * *$

\section{References}

ABIEC. Associação brasileira das indústrias exportadoras de carne: rebanho bovino brasileiro, 2012. Disponível em: http://www.abiec.com.br/. Acesso em: 5 de novembro de 2017.

ALBUQUERQUE, L.G.; MEYER, K. Estimates of direct and maternal genetic effects for weights from birth to 600 days of age in Nelore cattle. Journal Animal Breeding Genetics, v.118, 83-92, 2001. https://doi.org/10.1046/j.14390388.2001.00279.x

AMARAL, R.S.; CARNEIRO, P.L.S.; MARTINS FILHO R.; AMBROSINI, D.P.; MALHADO, C.H.M. Tendências, parâmetros fenotípicos e genéticos de características de crescimento em bovinos Nelore mocho do Nordeste brasileiro. Revista Brasileira de Saúde e Produção Animal, v.15, 261-271, 2014. https://doi.org/10.1590/S1519-99402014000200003

CARDOSO, F.F.; CARDELlinO, R.A.; CAMPOS, L.T. Componentes de (co)variância e parâmetros genéticos para caracteres produtivos à desmama de bezerros Angus criados no Estado do Rio Grande do Sul. Revista Brasileira de Zootecnia, v.30, 41-48, 2001. https://doi.org/10.1590/S1516-35982001000100008

CARDOSO, F.F.; CARDELlinO, R.A.; CAMPOS, L.T. (2004). Componentes de (co)variância e parâmetros genéticos de caracteres pós-desmama em bovinos da 
Faria, Guimarães, Gomes, Miguel, Lemos, Pereira, Lôbo $\quad$ Bayesian analysis on the growth traits...

raça Angus. Revista Brasileira de Zootecnia, v.33, 313-319, 2004. https://doi.org/10.1590/S1516-35982004000200006

CONCEIÇÃO, F.M.; FERRAZ FILHO, P.B.; SILVA, L.O.C.; BRAGANÇA, V.L.C.; SOUZA, J.C. Fatores ambientais que influenciam o peso à desmama, ano e sobreano em bovinos da raça Nelore Mocha, no Sudeste de Mato Grosso do Sul Brasil. Archives of Veterinary Science, v.10, 157-165, 2005.

https://doi.org/10.5380/avs.v10i2.4432

FARIA, C.U.; MAGNABOSCO, C.U.M.; ALBUQUERQUE, L.G.; REYES, A.R.; BEZERRA, L.A.F.B; LÔBO, R.B. Estimativas de correlações genéticas entre escores visuais e características de crescimento em bovinos da raça Nelore utiliza modelos bayesianos linear-limiar. Ciência Animal Brasileira, v.9, p.327-340, 2008.

FERRAZ FILHO, P.B.; SILVA, L.O.C.; ALENCAR, M.M.; SOBRINHO, E.B.; SOUZA, J.C. Tendência genética em pesos de bovinos da raça Nelore Mocha no Brasil. Arquivos de Ciências Veterinárias e Zoologia da UNIPAR, v.5, 9-13, 2002.

FERREIRA J.L.; LOPES F.B.; MARQUES E.G.; SILVA M.C.; ASSIS A.S.; PEREIRA L.S.; NEPOMUCENO L.L. Estudo genético quantitativo em características produtivas de bovinos da raça Nelore criados na Região Norte do Brasil. Revista Brasileira de Medicina Veterinária, v. 36, 11-17, 2014.

GARNERO, A. DEL V.; LÔBO, R.B.; BEZERRA, L.A.F.; OLIVEIRA, H.N. Comparação entre alguns critérios de seleção para crescimento na raça Nelore. Revista Brasileira de Zootecnia, v.30, 714-718, 2001.

https://doi.org/10.1590/S1516-35982001000300016

GARNERO, A.V.; MUÑOZ, M.C.C.D.; MARCONDES, C.R.; LÔBO, R.B.; LIRA, T.; GUNSKI, R.J. Estimação de parâmetros genéticos entre pesos pré e pós-desmama na raça Nelore. Archivos de Zootecnia, v.59, 307-310, 2010. https://doi.org/10.4321/ $\underline{\text { S0004-05922010000200019 }}$ 
Faria, Guimarães, Gomes, Miguel, Lemos, Pereira, Lôbo $\quad$ Bayesian analysis on the growth traits...

GONÇALVES, F.M.; PIRES, A.V.; PEREIRA, I.G.; GARCIA, D.A.; FARAH, M.M.; MEIRA, C.T.; CRUZ, V.A.R. Avaliação genética para peso corporal em um rebanho Nelore. Arquivo Brasileiro de Medicina Veterinária e Zootecnia, v.63, 158-164. https://doi.org/10.1590/S0102-09352011000100024

GUNSKI, R.J.; GARNERO, A.V.; REYES, A.B.; BEZERRA, L.A.F.; LÔBO, R.B. Estimativas de parâmetros genéticos para características incluídas em critérios de seleção em gado Nelore. Ciência Rural, v.31, 603-607, 2001. https://doi.org/10.1590/ $\underline{\mathrm{S} 0103-84782001000400007}$

LAUREANO, M.M.M.; BOLIGON, A.A.; COSTA, R.B.; FORNI, S.; SEVERO, J.L.P.; ALBUQUERQUE, L.G. Estimativas de herdabilidade e tendências genéticas para características de crescimento e reprodutivas em bovinos da raça Nelore. Arquivo Brasileiro de Medicina Veterinária e Zootecnia, v.63, 143-152, 2011. https://doi.org/10.1590/S0102-09352011000100022

LIMA, A.E.S.; FERRAZ FILHO, P.B.; SILVA, L.O.C.; SOUZA, J.C.; GONDO, A. Efeitos genéticos diretos e maternos e suas tendências em pesos à desmama de bovinos da raça Nelore Mocha, na região pecuária de Goiás. Archives of Veterinary Science, v.10, 69-74, 2005. https://doi.org/10.5380/avs.v10i2.4419

MALHADO, C.H.M.; CARNEIRO, P.L.S.; MARTINS FILHO, R.; AZEVEDO, D.M.M.R.; FACO, O.; MACHADO, C.H.C.; PICCININ, A. Tendência e parâmetros genéticos paro o peso aos 205 dias de idade em bovinos da raça Nelore Mocho no estado da Bahia. Revista Científica de Produção Animal, v.7, 28-34, 2005.

MARCONDES, C.R.; BERGMANN, J.P.; ELER, J.B.S.; FERRAZ, J.B.S.; PEREIRA, J.C.C.; PENNA, V.M. Análise de alguns critérios de seleção para características de crescimento na raça Nelore. Arquivo Brasileiro de Medicina Veterinária e Zootecnia, v.52, 83-89, 2000.

https://doi.org/10.1590/S0102-09352000000100018 
NEPOMUCENO, L.L.; LIRA, T.S.; LOPES, F.B.; LÔBO, R.B.; FERREIRA, J.L. Interação genótipo-ambiente para características sob efeito maternal na raça Nelore nos estados do Maranhão, Mato Grosso e Pará. Revista Brasileira de Saúde e Produção Animal, v.14, 269-276, 2013. https://doi.org/10.1590/S1519$\underline{99402013000200002}$

PAYÁ, S.B.; SIMÕES, A.C.; FERRAZ FILHO, P.B.; SILVA, L.O.C.; SOUZA, J.C. Causas de variações não genéticas e interações estação $\mathrm{x}$ região em pesos de animais de rebanhos Nelore Mocho em áreas inclusas na região pecuária leiteira. Archives of Veterinary Science, v.12, 8-12, 2007.

https://doi.org/10.5380/avs.v12i2.9902

SANTOS, P.F.; MALHADO, C.H.M.; CARNEIRO, P.L.S.; MARTINS FILHO, R.; AZEVÊDO, D.M.M.R.; CUNHA, E. E.; FERRAZ FILHO, P.B. Correlação genética, fenotípica e ambiental em características de crescimento de bovinos da raça Nelore variedade Mocha. Archives of Veterinary Science, v.10, 55-60, 2005.

https://doi.org/10.5380/avs.v10i2.4414

SILVA, J.A.V.; DIAS, L.T.; ALBUQUERQUE, L.G. Estudo genético da precocidade sexual de novilhas em um rebanho Nelore. Revista Brasileira de Zootecnia, v.32, 1568-1572, 2005. https://doi.org/10.1590/S1516-35982005000500017

SILVA, R.M.; SOUZA, J.C.; SILVA, L.O.C.; SILVEIRA, M.V.; FREITAS, J.A.; MARÇAL, M.F. Parâmetros e tendências genéticas para pesos de várias idades em bovinos Nelore. Revista Brasileira de Saúde e Produção Animal, v.14, 21-28, 2013. https://doi.org/10.1590/S1519-99402013000100003

SIQUEIRA, R.L.P.G.; OLIVEIRA, J.A.; LÔBO, R.B.; BEZERRA, L.A.F.; TONHATI, H. Análise da variabilidade genética aditiva de características de crescimento da raça Nelore. Revista Brasileira de Zootecnia, v.32, 99-105, 2003.

https://doi.org/10.1590/S1516-35982003000100013 
Faria, Guimarães, Gomes, Miguel, Lemos, Pereira, Lôbo $\quad$ Bayesian analysis on the growth traits...

SENA, J.S.S.; MATOS, A.S.; MARCONDES, C.R.; BEZERRA L.A.F.; LÔBO, R.B. Parâmetros genéticos, tendências e resposta à seleção de características produtivas da raça Nelore na Amazônia Legal. Atas de Saúde Ambiental, v.1, 2-12, 2013.

SOUZA, M.C.A.; FERRAZ FILHO, P.B.; SILVA, L.O.C.; SOUZA, J.C.; MALHADO, C.H.M. Efeitos genéticos e ambientais sobre pesos à desmama de bovinos da raça Nelore Mocha, na região pecuária oeste São Paulo - Paraná. Archives of Veterinary Science, v.9, 113-118, 2004. https://doi.org/10.5380/avs.v9i2.4074

SAS Institute INC. SAS OnlineDoc® 9.1.3. Cary, NC: SAS Institute Inc., 2004.

VAN TASSEL, C.P., VAN VLECK, L.D. Multiple-trait Gibbs sampler for animal models: flexible programs for bayesian and likelihood-based (co)variance component inference. Journal Animal Science, v.74, 2586-2597, 1996. https://doi.org/10.2527/1996.74112586x 